\title{
The prevalence and risk factors of cytomegalovirus infection in inflammatory bowel disease in Wuhan, Central China
}

Fengming Yi ${ }^{1}$, Jie Zhao ${ }^{2}$, Rishi Vishal Luckheeram² ${ }^{2}$ Yuan Lei ${ }^{2}$, Changgao Wang ${ }^{2}$, Sha Huang ${ }^{2}$, Lu Song ${ }^{2}$, Wei Wang ${ }^{2}$ and Bing Xia ${ }^{1,2^{*}}$

\begin{abstract}
Background: The etiology of inflammatory bowel disease (IBD) is not clear and cytomegalovirus (CMV) infection is often associated with IBD patients. The etiologic link between IBD and CMV infection needs to be studied. The objective of the present study is to investigate the prevalence and risk factors of CMV in a cohort of IBD patients from Central China.

Methods: Two hundred and twenty six IBD patients (189 ulcerative colitis (UC) and 37 patients with Crohn's disease (CD)), and 290 age and sex matched healthy controls were recruited. CMV DNA was detected by nested PCR, while serum anti-CMV IgG and anti-CMV IgM was determined by ELISAs. Colonoscopy/enteroscopy with biopsy of diseased tissues and subsequent H\&E stain were then conducted in IBD patients with positive anti-CMV IgM. Finally, we analyzed the prevalence and clinical risk factors of CMV infection in IBD patients.
\end{abstract}

Results: The prevalence of CMV DNA and anti-CMV IgG positive rate in IBD patients were $84.07 \%$ and $76.11 \%$, respectively, higher than those in healthy controls (59.66\% and 50.69\%, respectively, $P<0.05)$, However, anti-CMV IgM positive rate was no different with healthy controls ( $1.77 \%$ vs $0.34 \%, P=0.235)$. In univariate analysis of risk factors, the recent use of corticosteroid was associated with increase of CMV DNA and IgM positive rate in UC ( $P=0.035$ and $P=0.015$, respectively), aminosalicylic acid drug therapy was correlated with positivity of CMV DNA and IgG in UC and CMV DNA in CD ( $P=0.041, P<0.001$ and $P=0.014$, respectively), the treatment of immunosuppresent was correlated with CMV IgM $(P<0.001)$. Furthermore, patients with severe UC were significantly associated with CMV DNA and $\operatorname{lgM}(P=0.048$ and $P=0.031$, respectively). Malnutrition (albumin $<35 \mathrm{G} / \mathrm{L})$ was also found to be related with $\mathrm{CMV}$ recent infection $(P=0.031)$. In multivariate analysis of risk factors in UC, pancolitis was significantly associated with CMV DNA positivity $(P=0.001)$. Severe $U C$ and pancolitis seemed to be related with IgG positivity. For CD, there was just single factor associated with CMV positive in each group, multivariate analysis was unnecessary.

Conclusions: CMV positive rate in IBD patients was significantly higher, than in healthy controls. The use of aminosalicylic acid, corticosteroid, immunosuppressants, pancolitis and severe IBD patients seemed to be more susceptible to CMV infection in univariate analysis of risk factors. However, no risk factor was found to be significantly correlated with CMV infection in multivariate analysis of risk factors.

Keywords: Inflammatory bowel disease, Ulcerative colitis, Crohn's disease, Cytomegalovirus, Risk factors

\footnotetext{
* Correspondence: bingxia2004@yahoo.com.cn

'Department of Gastroenterology, Zhongnan Hospital of Wuhan University School of Medicine, Donghu Road 169, Wuhan 430071, P.R. of China

${ }^{2}$ The Hubei Clinical Center \& Key Laboratory of Intestinal \& Colorectal Diseases, Wuhan 430071, P.R. of China
}

\section{() Biomed Central}

(c) 2013 Yi et al.; licensee BioMed Central Ltd. This is an Open Access article distributed under the terms of the Creative Commons Attribution License (http://creativecommons.org/licenses/by/2.0), which permits unrestricted use, distribution, and reproduction in any medium, provided the original work is properly cited. 


\section{Introduction}

Inflammatory bowel disease (IBD) including ulcerative colitis (UC) and Crohn's disease (CD), consists of chronic, non-specific inflammatory diseases of the gut with unknown etiology. According to a retrospective survey, the incidence and prevalence of IBD in China are on the rise [1], and IBD is gradually become one of the refractory intestinal diseases. Even though the etiology of IBD is unknown, recent studies have shown that the pathogenesis of IBD is related to susceptible genes, immune dysregulation and microbiota of the gut.

Cytomegalovirus (CMV) is a $\beta$ herpes virus with double-stranded DNA. Worldwide the current infective rate ranges between $40 \%$ and $100 \%$ [2]. Two studies in USA demonstrated that CMV positive rate in patients with acute severe colitis was $21-34 \%$, in corticosteroidrefractory cases was $33-36 \%$, and in active UC was $10 \%$ $[3,4]$. In Egypt, the CMV positive rate was $34.8 \%$ in corticosteroid-refractory IBD patients [2]. However, the prevalence of CMV in Chinese patients with IBD has not been reported in the literature till now.

CMV infection in IBD patients often makes clinical diagnosis and treatment complex. Maher et al. [2] have shown that IBD patients with CMV-positive were more likely to get fever, cervical lymphadenopathy, splenomegaly, leucopenia, thrombocytopenia, and pancolitis as compared to CMV-negative ones. Kandiel et al. [3] used antiviral drugs for the treatment of acute severe CMVpositive colitis, and achieved a remission rate of $67-$ 100\%. However, Lévêque et al. [5] found no relationship between CMV viral load and disease severity in patients with active IBD. Out of $7 \mathrm{CMV}$-positive patients treated with immunosuppressants and no antiviral therapy, remission was achieved in 5 patients. de Saussure et al. [6] treated $3 \mathrm{CMV}$-positive IBD cases with antiviral therapy, and only 1 patient got remission. Recently a study on cytomegalovirus infection in IBD undergoing treatment of anti-TNF- $\alpha$ antibody demonstrated that active CMV infection did not progress to CMV infection/disease following infliximab therapy, the response to infliximab therapy did not appear to be influenced by, or influence the course of, CMV infection/disease [7]. These studies aided in proving a link between CMV infection and refractory IBD. However, due to the small cohorts in some studies, further studies with larger cohorts need to be conducted in order to find a conclusive relationship between CMV and IBD.

Nested PCR of CMV-UL93 is considered to be a highly sensitive method for the detection of CMV [8]. Serum anti-CMV IgG and IgM are widely used in practice. The detection of IgG antibodies against CMV should be detected at the first visit, when the diagnosis of IBD is confirmed, in order to clarify whether the patient is at risk of displaying primary infection (IgG negative) or reactivation/reinfection (IgG positive). However, IgM antibodies to CMV are systematically detected in primary infection, reactivation or reinfection, it indicates CMV infection is in active stage. With primary infection, an early IgM antibody rise occurs and becomes detectable in the blood within the first week of infection. Anti-CMV IgM increases within 2 weeks of infection, and can remain positive for 3 months to 2 years. Its sensitivity and specificity for CMV infection could reach up to $100 \%$ and $98.6 \%$ respectively [9].

In this study, PCR detection of CMV DNA, and serological determinations of IgG and IgM were used to investigate the prevalence of CMV infection in IBD patients from central China. Moreover, risk factors for CMV infection in IBD patients were analyzed to find relationship between IBD and CMV infection.

\section{Methods}

\section{Patients and healthy controls}

From 2006 to 2011, 226 IBD patients (189 UC and 37 patients with $\mathrm{CD}$ ) were recruited from Zhongnan Hospital of Wuhan University School of Medicine. The diagnosis of $\mathrm{UC}$ and $\mathrm{CD}$ was based on clinical, laboratory, imaging, endoscopic and histological examinations, and in accordance to the Chinese Medical Association diagnostic criteria for IBD [10]. Clinical disease activity of $\mathrm{UC}$ and $\mathrm{CD}$ was assessed by Truelove and Witts criteria [11] and Crohn's disease activity index (CDAI) respectively [12].

Simultaneously, 290 sex and age matched healthy volunteers (controls) were recruited in Zhongnan Hospital Medical Center of Wuhan University, who attended this center for constitutional examination of health. All volunteers were unrelated to each other from Hubei province, and had no history of IBD, chronic infectious diseases, immune-mediated, ischemic and radiation-induced diseases. Subjects with history of use of corticosteroids and immunosuppressive agents, of drug abuse and unhealthy living were excluded from the study.

\section{Definitions}

The patients and controls were classified as current smokers if they had smoked more than 1 cigarette per day within 6 months before recruited, and nonsmokers if they never or rarely smoked. As for definition of alcohol drinking before the onset of symptoms, 3 categories were included: frequent drinking, light drinking and former drinking. Frequent drinking was defined as alcohol drinking 3 days or more per week for continuous 6 months before recruited, excluded drink everyday to alcoholic intoxication. Light drinking was defined as alcohol beverages less than 3 days per week. Former drinking was defined as patients who had quit drinking for more than 6 months before recruited. They were all 
defined as drinking. Non-drinking was defined as never or rarely drinking. Mixed food was defined as the composition of diet include vegetable and meat for at least 6 months before recruited. The severity of UC was assessed by Truelove and Witts criteria [11]: Severe diarrhoea (six or more motions a day) with macroscopic blood in stools. Fever (mean evening temperature more than $37.5^{\circ} \mathrm{C}$, or a temperature of $37.8^{\circ} \mathrm{C}$, or more on at least two days out of four). Tachycardia (mean pulse rate more than 90 per minute). Anaemia (haemoglobin 75\% or less-allowance made for recent transfusion). ESR much raised (more than $30 \mathrm{~mm}$ in one hour). Mild diarrhoea (four or less motions a day) with no more than small amounts of macroscopic blood in stools. No fever. No tachycardia. Anaemia not severe. ESR not raised above $30 \mathrm{~mm}$. in one hour. Moderately-Intermediate between severe and mild [11]. The severity of CD was classified by Best CDAI: Index values between 150 and 220 are associated with mild disease; values between 220 and 450 are moderate disease; and values above 450 are seen with severe disease [12]. Drugs use was defined as taking related drugs for a period of at least 2 months to the time recruited.

\section{Ethics statement}

The ethic committee of Zhongnan Hospital of Wuhan University approved the study. Consent was written by all subjects. Consent informed in current ethics statement was obtained from all participants involved in this study.

\section{Extraction of DNA}

$5 \mathrm{ml}$ venous blood was taken in anticoagulated tubes with ethylenediamine tetraacetic acid (EDTA) from all subjects, followed by centrifugation. $2 \mathrm{ml}$ of sera was taken and stored at -80 degrees for further anti-CMV IgG and IgM assay. Genomic DNA was extracted using proteinase $\mathrm{K}$ and phenol/chloroform method, which was then subsequently stored at -80 degrees.

\section{CMV-UL93 fragment detection}

The CMV-UL93 fragment was retrieved from NCBI and BLAST, and was imported into Primer 5.0, according to the primer design principle. Lateral primers consisted of an upstream primer 5'-GGCAGCTATCGTGACTG GGA-3', and a downstream primer 5'-GATCCGACC CATTGTCTAAA- $3^{\prime}$. PCR conditions included 40 cycles of $95^{\circ} \mathrm{C}$ for $10 \mathrm{~min}, 95^{\circ} \mathrm{C}$ for $30 \mathrm{~s}, 57^{\circ} \mathrm{C}$ for $30 \mathrm{~s}, 72^{\circ} \mathrm{C}$ for $60 \mathrm{~s}$, and then followed by $72^{\circ} \mathrm{C}$ for $10 \mathrm{~min}$. Inner primers were an upstream primer $5^{\prime}$-TTAGCGCGT GACCTGTTACG-3', and a downstream primer $5^{\prime}$ TCTAAATTGTTACGCAGTCCG-3'. PCR conditions included 40 cycles of $95^{\circ} \mathrm{C}$ for $10 \mathrm{~min}, 95^{\circ} \mathrm{C}$ for $30 \mathrm{~s}$, $58^{\circ} \mathrm{C}$ for $30 \mathrm{~s}, 72^{\circ} \mathrm{C}$ for $60 \mathrm{~s}$, and finally followed by $72^{\circ} \mathrm{C}$ for $10 \mathrm{~min}$. Then electrophoresis using $2.5 \%$ agarose gel, of the medial segment was done to identify the products of PCR. Direct sequence for PCR products was done for detection of positive and negative PCR products. DNAPCR+ was according to the result of electrophoresis of nested PCR, and ensured the result by DNA sequencing.

\section{Serum anti-CMV IgG and IgM detection}

ELISA kit (DIESSE Diagnostica senese, Italy) was used to detect serum anti-CMV IgG and IgM in IBD patients and healthy controls. CMV IgG+ and CMV IgM+ were according to the kit: Positive defined as optical density (OD) ratio of sample to standard threshold value greater than 1.1, negative below 0.9 .

\section{Histology and hematoxylin and eosin (H\&E) staining}

Colonoscopy and/or enteroscopy were conducted in anti-CMV IgM-positive IBD patients, and biopsies from pathological sites were taken. H\&E staining for the detection of CMV was done.

\section{Statistical analysis}

SPSS 13.0 software (SPSS for Windows version 13.0, Chicago, IL, USA) was used to conduct the statistical analysis. Measurement data are presented as mean \pm standard deviation (SD), and numeration data are expressed as percentage and the number of cases. Independent samples were analyzed by Levene's test. $\chi^{2}$ (Chisquare) test with Yates continuity correction or Fisher's exact test was performed to compare frequencies of risk factors between the IBD patients and healthy controls. Multiple logistic regression analysis was performed to evaluate multiple risk factors for IBD. Odds ratio (OR) and $95 \%$ confidence intervals $(\mathrm{CI})$ were calculated. All calculated $P$-values were 2 -sided and $P<0.05$ was considered significant.

\section{Results}

\section{Demographic and clinical profile}

As shown in Table 1, Patients with inflammatory bowel disease and heathy controls were age- and sex-matched $(P>0.05)$, demographic and clinical profile were included in this table.

\section{CMV-UL93 fragment, and CMV IgG, IgM detection}

As shown in Table 2, prevalence of CMV-UL93 and anti-CMV IgG were significantly higher in IBD patients, than in healthy controls $(84.07 \%$ vs $59.66 \%, P<0.001$; $76.11 \%$ vs $50.69 \%, P<0.001)$, However, prevalence of anti-CMV IgM was no different with healthy controls (1.77\% vs $0.34 \%, P=0.235)$. For UC patients, CMVUL93 and anti-CMV IgG were all significantly higher than in healthy controls $(P<0.001$ and $P<0.001$, respectively), While there was no difference between UC 
Table 1 Demographic and clinical profile of the inflammatory bowel disease patients and healthy controls

\begin{tabular}{|c|c|c|c|c|c|}
\hline & $\begin{array}{c}\text { UC } \\
n=189(\%)\end{array}$ & $\begin{array}{c}C D \\
\mathrm{n}=\mathbf{3 7}(\%)\end{array}$ & $\begin{array}{c}\text { IBD } \\
n=226(\%)\end{array}$ & $\begin{array}{l}\text { Healthy controls } \\
n=290(\%)\end{array}$ & $P$ value \\
\hline Mean age \pm SD (yr) & $40.81 \pm 15.00$ & $38.78 \pm 14.14$ & $40.66 \pm 14.90$ & $38.08 \pm 14.63$ & 0.888 \\
\hline Male/Female & $109 / 80$ & $23 / 14$ & $132 / 94$ & $170 / 120$ & 0.961 \\
\hline Smoking & 45 (23.81\%) & $9(24.32 \%)$ & 54 (23.89\%) & $101(34.83 \%)$ & $0.007^{*}$ \\
\hline Drinking & 75 (39.68\%) & $12(32.43 \%)$ & 87 (38.50\%) & 133 (45.86\%) & 0.093 \\
\hline \multicolumn{6}{|l|}{ Diet composition } \\
\hline vegetarian food & $18(9.52 \%)$ & $6(16.22 \%)$ & 24 (10.62\%) & $19(6.55 \%)$ & 0.097 \\
\hline mixed food & $171(90.48 \%)$ & $31(83.78 \%)$ & $202(89.38 \%)$ & $271(93.45 \%)$ & \\
\hline \multicolumn{6}{|l|}{ General state } \\
\hline fever & 32 (16.93\%) & $4(10.81 \%)$ & 36 (15.93\%) & & \\
\hline hemoglobin (g/L) & $114.10 \pm 23.98$ & $121.22 \pm 25.34$ & $115.71 \pm 24.37$ & & \\
\hline albumin (g/L) & $39.97 \pm 5.88$ & $38.12 \pm 6.44$ & $39.94 \pm 6.04$ & & \\
\hline \multicolumn{6}{|l|}{ Disease extent } \\
\hline distal colitis & $140(74.07 \%)$ & & & & \\
\hline pancolitis & 49 (25.93\%) & & & & \\
\hline ileal & & $8(21.62 \%)$ & & & \\
\hline colonic & & $14(37.84 \%)$ & & & \\
\hline ileocolonic & & $15(44.11 \%)$ & & & \\
\hline \multicolumn{6}{|l|}{ Disease severity } \\
\hline $\mathrm{mild} /$ moderate & 168 & 30 & & & \\
\hline severe & $21(11.1 \%)$ & 7 (18.92\%) & & & \\
\hline \multicolumn{6}{|l|}{ Treatment } \\
\hline ASA/SASP & 149 (78.84\%) & $20(54.05 \%)$ & $169(74.78 \%)$ & & \\
\hline corticosteroids & 47 (24.87\%) & $8(21.62 \%)$ & 55 (24.34\%) & & \\
\hline immunodepressant & $5(2.65 \%)$ & $2(5.41 \%)$ & 7 (3.10\%) & & \\
\hline
\end{tabular}

$C M V$, cytomegalovirus; UC, ulcerative colitis; $C D$, Crohn's disease; $A S A$, aminosalicylic acid; SASP, salicylazosulfapyridine.

*indicate significant difference.

Table 2 Prevalence of cytomegalovirus (CMV) in patients with inflammatory bowel disease and healthy controls

\begin{tabular}{|c|c|c|c|c|}
\hline & $\begin{array}{c}\text { IBD } \\
(n=226)\end{array}$ & $\begin{array}{c}\text { UC } \\
(n=189)\end{array}$ & $\begin{array}{c}C D \\
(n=37)\end{array}$ & $\begin{array}{l}\text { Healthy controls } \\
\quad(n=290)\end{array}$ \\
\hline CMV detection & n (\%) & n (\%) & n (\%) & $\mathrm{n}(\%)$ \\
\hline DNA DNA+ & $90(84.07)^{\mathrm{a}}$ & $161(85.19)^{d}$ & $29(78.38)^{9}$ & $173(59.66)$ \\
\hline Serum CMV IgG+ & $172(76.11)^{b}$ & $139(73.54)^{\mathrm{e}}$ & $33(89.19)^{h}$ & $147(50.69)$ \\
\hline Serum CMV IgM+ & $4(1.77)^{c}$ & $3(1.59)^{f}$ & $1(2.70)^{i}$ & $1(0.34)$ \\
\hline
\end{tabular}

a Compare with healthy controls, $\mathrm{OR}=3.569,95 \% \mathrm{Cl}: 2.330-5.468, P<0.001$;

b Compare with healthy controls, $\mathrm{OR}=3.099,95 \% \mathrm{Cl}: 2.113-4.543, P<0.001$;

c Compare with healthy controls, OR $=5.207,95 \% \mathrm{Cl}: 0.578-46.914, P=0.235$;

d Compare with healthy controls, $\mathrm{OR}=3.889,95 \% \mathrm{Cl}: 2.443-6.190, P<0.001$;

e Compare with healthy controls, $\mathrm{OR}=2.704,95 \% \mathrm{Cl}: 1.819-4.022, P<0.001$;

f Compare with healthy controls, $\mathrm{OR}=4.661,95 \% \mathrm{Cl}: 0.481-45.148, P=0.344$;

g Compare with healthy controls, $\mathrm{OR}=2.452,95 \% \mathrm{Cl}: 1.083-5.550, P=0.027$;

h Compare with healthy controls, $\mathrm{OR}=8.026,95 \% \mathrm{Cl}: 2.772-23.232, P<0.001$;

i Compare with healthy controls, OR= 8.028, 95\% Cl:0.491-131.142, $P=0.540$.

$\mathrm{IBD}$, inflammatory bowel disease; CMV, cytomegalovirus; UC, ulcerative colitis; CD, Crohn's disease. 
and healthy controls for anti-CMV IgM $(P=0.344)$. For CD patients, CMV-UL93 and anti-CMV IgG were higher than in controls $(P=0.027$ and $P<0.001$, respectively), while anti-CMV IgM was not increased as compared to healthy controls $(P=0.540)$.

However, in biopsies taken from the pathological sites of intestinal mucosa of anti-CMV IgM positive IBD patients, no inclusion bodies were detected in $\mathrm{H} \& \mathrm{E}$ stain.

\section{Univariate Analysis of Risk factors for CMV positive in patients with IBD}

In UC patients, elevated CMV-DNA was mainly associated with the severity of disease activity $(P=0.048)$, use of ASA/SASP (aminosalicylic acid/salicylazosulfapyridine) and corticosteroids therapy $(P=0.041$ and $P=$ 0.035 , respectively), while other factors, such as age, sex, smoking, alcohol consumption, type of diet, fever, anemia, albumin level, disease location, treatment with immunosuppressive agents had not shown significant association $(P>0.05)$. As for $C D$ patients, CMV DNA positive was positively associated with use of 5-ASA/ SASP $(P=0.014)$, as seen in Table 3 .

In UC patients, anti-CMV IgG level was associated with the use of 5 -aminosalicylic acid $(P<0.001)$ as shown in Table 4. CD patients on vegetarian diet had much lower anti-CMV IgG positive rate, than those on non-vegeterian diet $(P=0.010)$. Other factors had no statistically significant impact on anti-CMV IgG positive rate $(P>0.05)$.

The positive rate of anti-CMV IgM in UC patients, was associated with low albumin level $(P=0.031)$, severe UC $(P=0.031)$, use of corticosteroids $(P=0.015)$, and the use of immunosuppressive agents $(P<0.001)$, while other factors did not cause any statistically significant changes in anti-CMV IgM positive rate $(P>0.05)$. In CD patients, no statistically significant association with antiCMV IgM was found, as shown in Table 5.

\section{Multivariate analysis by logistic regression for CMV positive in IBD}

As shown in Table 6. In multivariate analysis of risk factors in UC, pancolitis was significantly associated with CMV DNA elevated $(P=0.001)$. Severe UC and pancolitis seemed to be related with IgG positive $(P=0.021$ and $P=0.017$, respectively). For $C D$, there was just single factor associated with CMV positive in each group, multivariate analysis was unnecessary.

\section{Discussion}

CMV is an opportunistic pathogenic microorganism. In vivo it can proliferate in epitheliums, white blood cells and sperm cells, and it is prone to cause latent infection of salivary gland, mammary gland, kidney and white blood cells. In IBD patients, immunosuppressive therapy, impaired absorption of nutrients, dysfunction of the immune system, render them susceptible to CMV infection [13], which is consistent with the high infective rate of CMV in immunosuppressed individuals, such as acquired immunodeficiency syndrome (AIDS), transplant recipients, cancer, chemotherapy, but rare in immunocompetent individuals.

The detection methods of CMV infection in IBD patients included DNA detection, serological tests (serum anti-CMV IgM, IgG), histopathology (inclusion bodies detection) in this study. Body fluids or tissue sample was feasible to CMV culture, but it was timeconsuming and also had low sensitivity, which limited clinical application [14]. The detection of CMV-DNA was considered as the most sensitive method [15], but it was associated with false positive results, thereby decreasing its specificity. Increase in serum anti-CMV IgM level occurred in recent CMV infection and it had high sensitivity and specificity [9], while anti-CMV IgG indicated past CMV infection. Sensitivity of H\&E was $10 \%$ to $87 \%$ [3], CMV inclusion bodies could be found in biopsy specimens from colon with inflamed and ulcerated mucosa [16]. We used CMV-DNA specific fragment UL93, anti-CMV IgG and IgM to detect CMV infection in IBD patients and healthy controls. Positive rates in IBD patients were $84.07 \%, 76.11 \%, 1.77 \%$ for CMV DNA, anti-CMV IgG and IgM respectively, and 59.66\%, $50.69 \%, 0.34 \%$ for healthy controls. CMV-UL93 and anti-CMV IgG were significantly higher in IBD patients as compared to controls, thereby indicating the association between IBD and CMV.

The positive rate of CMV UL-93 or anti-CMV IgG in the healthy controls was about $50-60 \%$, whereas in IBD patients it was around $70-80 \%$. A research conducted in India showed the CMV DNA positive rate was just $12.70 \%$ in IBD patients [17], which was remarkably lower than in our country. The small number of subjects enrolled (63 IBD patients) could account for the low positive rate in the Indian study. Another research done in France showed $60 \%$ positive rate in IBD patients [18], which was consistent with our research. In developed countries, the anti-CMV IgG positive rate was found to be above $70 \%$ [19].

Anti-CMV IgM positive rate is only $1.77 \%$ in our research, which was lower as compared to an Indian study, including IBD patients with both active disease and in remission [17], where the rate was 9.52\%. Anti-CMV IgM positive rate in healthy controls $(0.34 \%)$ was no different with IBD patients $(P=0.235)$, which was related with small amount of people included.

Presence of anti-CMV IgM indicated recent infection of CMV. However in biopsies taken from the pathological sites of intestinal mucosa of anti-CMV IgM positive IBD patients, no inclusion bodies was detected. This 
Table 3 Univariate analysis of risk factors for CMV DNA positive in patients with inflammatory bowel disease

\begin{tabular}{|c|c|c|c|c|c|c|}
\hline \multirow[b]{3}{*}{ Age } & \multicolumn{6}{|c|}{ CMV DNA+/DNA- } \\
\hline & \multicolumn{3}{|c|}{$\begin{array}{c}\text { UC } \\
(161 / 28) \\
\end{array}$} & \multicolumn{3}{|c|}{$\begin{array}{c}C D \\
(29 / 8) \\
\end{array}$} \\
\hline & Number & $P$ value & OR $(95 \% \mathrm{Cl})$ & Number & $P$ value & OR $(95 \% \mathrm{Cl})$ \\
\hline$\leq 50$ ys & $117 / 22$ & 0.514 & $0.725(0.276 \sim 1.907)$ & $18 / 6$ & 0.685 & $0.545(0.093 \sim 3.194)$ \\
\hline$>50$ ys & $44 / 6$ & & & $11 / 2$ & & \\
\hline \multicolumn{7}{|l|}{ Sex } \\
\hline male & $95 / 14$ & 0.373 & $1.439(0.644 \sim 3.218)$ & $19 / 4$ & 0.445 & $1.900(0.390 \sim 9.256)$ \\
\hline female & $66 / 14$ & & & $10 / 4$ & & \\
\hline \multicolumn{7}{|l|}{ Smoking } \\
\hline yes & $40 / 5$ & 0.423 & $1.521(0.542 \sim 4.264)$ & $7 / 2$ & 1.000 & $0.840(0.138 \sim 5.115)$ \\
\hline no & $121 / 23$ & & & $25 / 6$ & & \\
\hline \multicolumn{7}{|l|}{ Drinking } \\
\hline Yes & $62 / 13$ & 0.429 & $0.723(0.322 \sim 1.621)$ & $9 / 3$ & 0.403 & $0.500(0.100 \sim 2.510)$ \\
\hline no & $99 / 15$ & & & $30 / 5$ & & \\
\hline \multicolumn{7}{|l|}{ Diet composition } \\
\hline vegetarian food & $15 / 3$ & 1.000 & $0.856(0.231 \sim 3.174)$ & $3 / 3$ & 0.101 & $0.192(0.030 \sim 1.241)$ \\
\hline mixed food & $146 / 25$ & & & $26 / 5$ & & \\
\hline \multicolumn{7}{|l|}{ Fever } \\
\hline yes & $30 / 2$ & 0.221 & $2.977(0.670 \sim 13.235)$ & $4 / 0$ & 0.557 & N/A \\
\hline no & $131 / 26$ & & & $25 / 8$ & & \\
\hline \multicolumn{7}{|l|}{ Hemoglobin(G/L) } \\
\hline$\leq 70$ & $8 / 1$ & 1.000 & $1.412(0.170 \sim 11.747)$ & $0 / 0$ & - & N/A \\
\hline$>70$ & $153 / 27$ & & & $29 / 8$ & & \\
\hline \multicolumn{7}{|l|}{ Albumin(G/L) } \\
\hline$\leq 35$ & $18 / 3$ & 1.000 & $1.049(0.288 \sim 3.826)$ & $11 / 2$ & 0.685 & $1.833(0.313 \sim 10.735)$ \\
\hline$>35$ & $143 / 25$ & & & $18 / 6$ & & \\
\hline \multicolumn{7}{|l|}{ Disease severity } \\
\hline mild and moderate & $140 / 28$ & $0.048^{*}$ & N/A & $24 / 6$ & 0.631 & $1.600(0.247 \sim 10.360)$ \\
\hline severe & $21 / 0$ & & & $5 / 2$ & & \\
\hline \multicolumn{7}{|l|}{ Location } \\
\hline distal colitis & $123 / 17$ & 0.080 & $2.094(0.903 \sim 4.857)$ & & & \\
\hline pancolitis & $38 / 11$ & & & & & \\
\hline ileal & & & & $7 / 1$ & 0.734 & N/A \\
\hline Colonic & & & & $11 / 3$ & & \\
\hline ileocolon & & & & $11 / 4$ & & \\
\hline \multicolumn{7}{|l|}{ Treatment } \\
\hline ASA/SASP & $131 / 18$ & $0.041 *$ & $2.426(1.017 \sim 5.784)$ & $19 / 1$ & $0.014^{*}$ & $13.300(1.429 \sim 123.790)$ \\
\hline corticosteroids & $45 / 2$ & $0.035^{*}$ & $5.043(1.149 \sim 22.128)$ & $8 / 0$ & 0.160 & N/A \\
\hline immunosuppressant & $5 / 0$ & 1.000 & N/A & $2 / 0$ & 1.000 & N/A \\
\hline
\end{tabular}


Table 4 Univariate analysis of risk factors for CMV IgG positive in patients with inflammatory bowel disease

\begin{tabular}{|c|c|c|c|c|c|c|}
\hline \multirow[b]{3}{*}{ Age } & \multicolumn{6}{|c|}{ CMV IgG+/lgG- } \\
\hline & \multicolumn{3}{|c|}{$\begin{array}{c}\text { UC } \\
(139 / 50)\end{array}$} & \multicolumn{3}{|c|}{$\begin{array}{c}C \mathrm{CD} \\
(33 / 4)\end{array}$} \\
\hline & Number & $P$ value & OR $(95 \% \mathrm{Cl})$ & Number & $P$ value & OR $(95 \% \mathrm{Cl})$ \\
\hline$\leq 50$ ys & $107 / 32$ & 0.074 & $1.881(0.934 \sim 3.786)$ & $21 / 3$ & 1.000 & $0.583(0.054 \sim 6.251)$ \\
\hline$>50$ ys & $32 / 18$ & & & $12 / 1$ & & \\
\hline \multicolumn{7}{|l|}{ Sex } \\
\hline male & $82 / 27$ & 0.540 & $1.225(0.639 \sim 2.349)$ & $21 / 2$ & 0.625 & $1.750(0.218 \sim 14.069)$ \\
\hline female & $57 / 23$ & & & $12 / 2$ & & \\
\hline \multicolumn{7}{|l|}{ Smoking } \\
\hline yes & $32 / 13$ & 0.672 & $0.851(0.404 \sim 1.793)$ & $9 / 0$ & 0.554 & N/A \\
\hline no & $107 / 37$ & & & $24 / 4$ & & \\
\hline \multicolumn{7}{|l|}{ Drinking } \\
\hline Yes & $53 / 22$ & 0.467 & $0.784(0.407 \sim 1.510)$ & $10 / 2$ & 0.582 & $0.435(0.053 \sim 3.536)$ \\
\hline no & $86 / 28$ & & & $23 / 2$ & & \\
\hline \multicolumn{7}{|l|}{ Diet composition } \\
\hline vegetarian food & $14 / 4$ & 0.883 & $1.288(0.403 \sim 4.115)$ & $3 / 3$ & $0.010^{*}$ & $0.033(0.003 \sim 0.429)$ \\
\hline mixed food & $125 / 46$ & & & $30 / 1$ & & \\
\hline \multicolumn{7}{|l|}{ Fever } \\
\hline yes & $26 / 6$ & 0.278 & $1.687(0.650 \sim 4.379)$ & $4 / 0$ & 1.000 & N/A \\
\hline no & $113 / 44$ & & & $29 / 4$ & & \\
\hline \multicolumn{7}{|l|}{ Hemoglobin (G/L) } \\
\hline$\leq 70$ & $7 / 2$ & 1.000 & $1.273(0.255 \sim 6.341)$ & $0 / 0$ & - & N/A \\
\hline$>70$ & $132 / 48$ & & & $33 / 4$ & & \\
\hline \multicolumn{7}{|l|}{ Albumin (G/L) } \\
\hline$\leq 35$ & $16 / 5$ & 0.771 & $1.171(0.405 \sim 3.381)$ & $11 / 2$ & 0.602 & $0.500(0.062 \sim 4.040)$ \\
\hline$>35$ & $123 / 45$ & & & $22 / 2$ & & \\
\hline \multicolumn{7}{|l|}{ Disease severity } \\
\hline mild and moderate & $120 / 48$ & 0.109 & $0.263(0.059 \sim 1.173)$ & $26 / 4$ & 0.570 & N/A \\
\hline severe & $19 / 2$ & & & $7 / 0$ & & \\
\hline \multicolumn{7}{|l|}{ Location } \\
\hline distal colitis & $108 / 32$ & 0.058 & $1.960(0.971 \sim 3.955)$ & & & \\
\hline pancolitis & $31 / 18$ & & & & & \\
\hline ileal & & & & $7 / 1$ & 0.219 & N/A \\
\hline Colonic & & & & $14 / 0$ & & \\
\hline ileocolon & & & & $12 / 3$ & & \\
\hline \multicolumn{7}{|l|}{ Treatment } \\
\hline ASA/SASP & $119 / 30$ & $<0.001^{*}$ & $3.967(1.897 \sim 8.296)$ & $18 / 2$ & 1.000 & $1.200(0.150 \sim 9.570)$ \\
\hline corticosteroids & $38 / 9$ & 0.190 & $1.714(0.761 \sim 3.861)$ & $8 / 0$ & 0.557 & N/A \\
\hline immunosuppressant & $5 / 0$ & 0.328 & $\mathrm{~N} / \mathrm{A}$ & $2 / 0$ & 1.000 & N/A \\
\hline
\end{tabular}


Table 5 Univariate analysis of risk factors for CMV IgM positive in patients with inflammatory bowel disease

\begin{tabular}{|c|c|c|c|c|c|c|}
\hline \multirow[b]{3}{*}{ Age } & \multicolumn{6}{|c|}{ CMV IgM+/lgM- } \\
\hline & \multicolumn{3}{|c|}{$\begin{array}{c}\text { UC } \\
(3 / 186)\end{array}$} & \multicolumn{3}{|c|}{$\begin{array}{c}C D \\
(1 / 36)\end{array}$} \\
\hline & Number & $P$ value & OR $(95 \% \mathrm{Cl})$ & Number & $P$ value & OR $(95 \% \mathrm{Cl})$ \\
\hline$\leq 50$ ys & 2/137 & 1.000 & $0.715(0.063 \sim 8.065)$ & $1 / 23$ & 1.000 & N/A \\
\hline$>50$ ys & $1 / 49$ & & & $0 / 13$ & & \\
\hline \multicolumn{7}{|l|}{ Sex } \\
\hline male & $2 / 107$ & 1.000 & $1.477(0.132 \sim 16.573)$ & $1 / 22$ & 1.000 & N/A \\
\hline female & $1 / 79$ & & & $0 / 14$ & & \\
\hline \multicolumn{7}{|l|}{ Smoking } \\
\hline yes & $1 / 44$ & 1.000 & $1.614(0.143 \sim 18.222)$ & $1 / 8$ & 0.243 & N/A \\
\hline no & $2 / 142$ & & & $0 / 28$ & & \\
\hline \multicolumn{7}{|l|}{ Drinking } \\
\hline yes & $1 / 74$ & 1.000 & $0.757(0.067 \sim 8.496)$ & $0 / 12$ & 1.000 & N/A \\
\hline no & $2 / 112$ & & & $1 / 24$ & & \\
\hline \multicolumn{7}{|l|}{ Diet composition } \\
\hline vegetarian food & $0 / 18$ & 1.000 & N/A & $0 / 6$ & 1.000 & N/A \\
\hline mixed food & $3 / 168$ & & & $1 / 30$ & & \\
\hline \multicolumn{7}{|l|}{ Fever } \\
\hline yes & $1 / 31$ & 1.000 & $2.500(0.220 \sim 28.432)$ & $0 / 4$ & 1.000 & N/A \\
\hline no & $2 / 155$ & & & $1 / 32$ & & \\
\hline \multicolumn{7}{|l|}{ Hemoglobin (G/L) } \\
\hline$\leq 70$ & $1 / 8$ & 0.329 & $11.125(0.911 \sim 135.909)$ & $0 / 0$ & - & N/A \\
\hline$>70$ & $2 / 178$ & & & $1 / 36$ & & \\
\hline \multicolumn{7}{|l|}{ Albumin $(\mathrm{G} / \mathrm{L})$} \\
\hline$\leq 35$ & $2 / 19$ & $0.031^{*}$ & $17.579(1.522 \sim 203.083)$ & $1 / 12$ & 0.351 & N/A \\
\hline$>35$ & $1 / 167$ & & & $0 / 24$ & & \\
\hline \multicolumn{7}{|l|}{ Disease severity } \\
\hline mild and moderate & $1 / 167$ & $0.031^{*}$ & $0.057(0.005 \sim 0.657)$ & $1 / 29$ & 1.000 & N/A \\
\hline severe & $2 / 19$ & & & $0 / 7$ & & \\
\hline \multicolumn{7}{|l|}{ Location } \\
\hline distal colitis & $1 / 139$ & 0.337 & $0.169(0.015 \sim 1.907)$ & & & \\
\hline pancolitis & $2 / 47$ & & & & & \\
\hline ileal & & & & $1 / 7$ & 0.155 & N/A \\
\hline Colonic & & & & $0 / 14$ & & \\
\hline ileocolon & & & & $0 / 15$ & & \\
\hline \multicolumn{7}{|l|}{ Treatment } \\
\hline ASA/SASP & $3 / 146$ & 1.000 & N/A & $1 / 19$ & 1.000 & N/A \\
\hline corticosteroids & $3 / 44$ & $0.015^{*}$ & N/A & $0 / 8$ & 1.000 & N/A \\
\hline immunosuppressant & $3 / 2$ & $<0.001^{*}$ & N/A & $0 / 2$ & 1.000 & N/A \\
\hline
\end{tabular}


Table 6 Multivariate analysis by logistic regression for CMV positive in ulcerative colitis

\begin{tabular}{lll}
\hline Index & \multicolumn{1}{c}{ OR $(\mathbf{9 5 \%}$ Cl $)$} & $\boldsymbol{P}$ \\
\hline CMV DNA & $0.227(0.093 \sim 0.553)$ & $0.001^{*}$ \\
Location & $0.000(0.000 \sim)$ & 0.998 \\
Disease severity & $1.704(0.357 \sim 8.138)$ & 0.504 \\
Fever & $0.574(0.228 \sim 1.449)$ & 0.240 \\
Treatment of corticosteroids & $1.761(0.661 \sim 4.691)$ & 0.258 \\
Treatment of ASA/SASP & & \\
CMV IgG & $0.893(0.398 \sim 2.005)$ & 0.784 \\
Age & $2.482(1.145 \sim 5.380)$ & $0.021^{*}$ \\
Location & $0.078(0.009 \sim 0.635)$ & 0.017 * \\
Disease severity & $0.749(0.342 \sim 1.639)$ & 0.470 \\
Treatment of ASA/SASP & & \\
CMV IgM & $0.000(0.000 \sim)$ & 0.997 \\
Alb & $0.840(0.000 \sim)$ & 1.000 \\
Disease severity & $1.038(0.000 \sim)$ & 1.000 \\
Treatment of corticosteroids & $0.997(0.000 \sim)$ & 0.997 \\
\hline Treatment of immunodepressant & &
\end{tabular}

$C M V$, cytomegalovirus; $O R$, Odds ratio; $C l$, confidence interval; Alb, albumin; $A S A$, aminosalicylic acid; SASP, salicylazosulfapyridine.

*indicate significant difference.

was probably due to the low sensitivity of histological examination. The site from where the biopsy was taken, and the amount of tissue retrieved, may also influence the sensitivity of finding inclusion bodies. Next stage we should recruit enough biopsies and screen CMV by immunohistochemistry.

In a model of multivariate analysis adjusting for multiple factors for UC. Disease location seemed to be significantly associate with CMV infection or re-activation, this may be associated with the theory that CMV was prone to proliferate in granulation tissue [20]. Pancolitis involved with larger areas of ulcerative mucosa, which promote proliferation of CMV. Some researches [21] found that CMV was readily discovered in granulation tissue and tissue from deep ulcers, which suggested that CMV could penetrate inflamed mucosa via mononuclear cells, and then proliferate in the mucosa. A recent study [22] showed that the murine CMV (MCMV) could not induce acute colitis, but the latent MCMV infection could increase the severity of the dextran sulfate sodium (DSS) induced colitis. Moreover, acute MCMV infection could significantly increase the serum and intestinal natural killer cells, interleukin (IL)-6, TNF- $\alpha$, IFN- $\gamma$, indicating that CMV infection can modulate mucosal immunity, thereby increasing susceptibility to inflammation. CMV infection can also activate oncogenes, kinases, transcription factors inducing tumorigenesis, which may be one of the reasons of the higher incidence of colorectal cancer in IBD patients [23]. CMV played a role in the initiation and progression of inflammation in IBD. The treatment of 5-ASAs, corticosteroids and immunosupressents were no longer significant associated with CMV infection in multivariate analysis.

Currently there is no absolute indication for antiviral therapy in CMV-positive IBD patients. However Eddleston recommends antiviral therapy in immunocompetent [24]. Pfau [21] found out that ganciclovir could reduce mortality rate and surgical intervention rate, while de Saussure P [6] showed that antiviral therapy had no effect on the disease course.

In summary, as compared to healthy individuals, IBD patients have a predisposition to CMV infection. No risk factor was found to be significantly correlated with CMV infection in risk factors analysis.

\section{Abbreviations}

CMV: Cytomegalovirus; IBD: Inflammatory bowel disease; UC: Ulcerative colitis; CD: Crohn's disease; PCR: Polymerase chain reactio; OR: Odds ratio; Cl: Confidence interval; Alb: Albumin; H\&E: Hematoxylin and eosin; CDAl: Crohn's disease activity index; SD: Standard deviation; ASA: Aminosalicylic acid; SASP: Salicylazosulfapyridine.

\section{Competing interests}

The authors declare that they have no conflict of interests.

\section{Authors' contributions}

$F Y, J Z, Y L$ and BX conceived the study, participated in its design and coordination, and managed the preparation of the manuscript. CW and SH carried out the nested PCR, FY and LS carried out ELISAs, All authors participated in the recruitment of specimens and clinical data of patients and healthy controls. RL and FY participated in the manuscript writing. BX and FY performed the statistical analysis. WW participated in the manuscript revision. All authors read and approved the final manuscript.

\section{Acknowledgements}

We thank the numerous individuals who volunteered to participate in this study. The study was supported by Hubei Clinical Center \& Key Laboratory of intestinal \& colorectal diseases (2008BCC002), National University Students Innovation Training Project of China (S2009406), and the Ministry of Public Health of China (200802156, 201002020). The funders had no role in study design, data collection and analysis, decision to publish, or preparation of the manuscript.

Received: 15 March 2012 Accepted: 27 November 2012

Published: 1 February 2013

\section{References}

1. Jiang L, Xia B, Li J, Ye M, Yan W, Deng C, Ding Y, Luo H, Hou W, Zhao Q, Liu $\mathrm{N}$, Ren $\mathrm{H}, \mathrm{Hou} X, \mathrm{Xu} \mathrm{H}$ : Retrospective survey of 452 patients with inflammatory bowel disease in Wuhan city, central China. Inflamm Bowel Dis 2006, 12:212-217.

2. Maher MM, Nassar Ml: Acute cytomegalovirus infection is a risk factor in refractory and complicated inflammatory bowel disease. Dig Dis Sci 2009, 54:2456-2462

3. Kandiel A, Lashner B: Cytomegalovirus colitis complicating inflammatory bowel disease. Am J Gastroenterol 2006, 101:857-2865.

4. Kim JJ, Simpson N, Klipfel N, Debose R, Barr N, Laine L: Cytomegalovirus infection in patients with active inflammatory bowel disease. Dig Dis SCi 2010, 55:1059-1065.

5. Lévêque N, Brixi-Benmansour H, Reig T, Renois F, Talmud D, Brodard V Coste JF, De Champs C, Andréoletti L, Diebold MD: Low frequency of 
cytomegalovirus infection during exacerbations of inflammatory bowel diseases. J Med Virol 2010, 82:1694-1700.

6. de Saussure P, Lavergne-Slove A, Mazeron MC, Alain S, Matuchansky C, Bouhnik Y: A prospective assessment of cytomegalovirus infection in active inflammatory bowel disease. Aliment Pharmacol Ther 2004, 20:1323-1327.

7. D'Ovidio V, Vernia P, Gentile G, Capobianchi A, Marcheggiano A, Viscido A: Cytomegalovirus infection in inflammatory bowel disease patients undergoing anti-TNFa therapy. J Clin Virol 2008, 43:180-183.

8. Roback JD, Hillyer CD, Drew WL, Laycock ME, Luka J, Mocarski ES, Slobedman B, Smith JW, Soderberg-Naucler C, Todd DS, Woxenius S, Busch MP: Multicenter evaluation of PCR methods for detecting CMV DNA in blood donors. Transfusion 2001, 41:1249-1257.

9. Revello MG, Gerna G: Diagnosis and management of human cytomegalovirus infection in the mother, fetus, and newborn infant. Clin Microbiol Rev 2002, 15:680-715.

10. Chinese Medical Association: Chinese consensus on standard management of inflammatory bowel diseases. Zhonghua Xiao Hua Za Zhi 2007, 27:545-550

11. Truelove SC, Witts L: Cortisone in ulcerative colitis; final report on a therapeutic trial. Br Med J 1955, 2:1041-1048.

12. Best WR, Becktel JM, Singleton JW, Kern F Jr: Development of a Crohn's disease activity index.National cooperative Crohn's disease study. Gastroenterology 1976, 70:439-444.

13. Papadakis KA, Tung JK, Binder SW, Kam LY, Abreu MT, Targan SR, Vasiliauskas EA: Outcome of cytomegalovirus infections in patients with inflammatory bowel disease. Am J Gastroenterol 2001, 96:2137-2142.

14. Boeckh M, Boivin G: Quantitation of cytomegalovirus: methodologic aspects and clinical applications. Clin Microbiol Rev 1998, 11:533-554.

15. Numata $S$, Nakamura $Y$, Imamura $Y$, Honda J, Momosaki S, Kojiro M: Rapid quantitative analysis of human cytomegalovirus DNA by the real-time polymerase chain reaction method. Arch Pathol Lab Med 2005, 129:200-204

16. Hinnant KL, Rotterdam HZ, Bell ET, Tapper ML: Cytomegalovirus infection of the alimentary tract: a clinicopathological correlation. Am J Gastroenterol 1986, 81:944-950.

17. Kishore J, Ghoshal U, Ghoshal UC, Krishnani N, Kumar S, Singh M, Ayyagari A: Infection with cytomegalovirus in patients with inflammatory bowel disease: prevalence, clinical significance and outcome. J Med Microbiol 2004, 53:1155-1160.

18. Pofelski J, Morand P, Roblin X, Gratacap B, Nicod S, Bargues G, Seigneurin $J \mathrm{M}$, Bonaz B: Caractérisation moléculaire du cytomégalovirus dans le maladies inflammatoires cryptogénetiques de l'intestin. Gastroenterol Clin Biol 2005, 29:A9.

19. Dimitroulia E, Spanakis N, Konstantinidou AE, Legakis NJ, Tsakris A: Frequent detection of cytomegalovirus in the intestine of patients with inflammatory bowel disease. Inflamm Bowel Dis 2006, 12:879-884.

20. Yee YK, Wong SW, Szeto ML: Ulcerative colitis exacerbation associated with cytomegalovirus infection. Hong Kong Med J 1998, 4:437-439.

21. Pfau P, Kochman ML, Furth EE, Lichtenstein GR: Cytomegalovirus colitis complicating ulcerative colitis in the steroid-naive patient. Am J Gastroenterol 2001, 96:895-899.

22. Onyeagocha C, Hossain MS, Kumar A, Jones RM, Roback J, Gewirtz AT: Latent cytomegalovirus infection exacerbates experimental colitis. Am J Pathol 2009, 175:2034-2042.

23. Harkins L, Volk AL, Samanta M, Mikolaenko I, Britt WJ, Bland Kl, Cobbs CS: Specific localisation of human cytomegalovirus nucleic acids and proteins in human colorectal cancer. Lancet 2002, 360:1557-1563.

24. Eddleston $M$, Peacock $S$, Juniper $M$, Warrell DA: Severe cytomegalovirus infection in inmmunocompetent patients. Clin Infect Dis 1997, 24:52-56.

doi:10.1186/1743-422X-10-43

Cite this article as: $Y i$ et al:: The prevalence and risk factors of cytomegalovirus infection in inflammatory bowel disease in Wuhan, Central China. Virology Journal 2013 10:43.

\section{Submit your next manuscript to BioMed Central and take full advantage of:}

- Convenient online submission

- Thorough peer review

- No space constraints or color figure charges

- Immediate publication on acceptance

- Inclusion in PubMed, CAS, Scopus and Google Scholar

- Research which is freely available for redistribution

Submit your manuscript at www.biomedcentral.com/submit
C Biomed Central 